\title{
Hubungan Pengetahuan dan Sikap Wanita Usia Subur terhadap Pemakaian Alat Kontrasepsi Hormonal Suntik di Puskesmas Kecamatan Lowokwaru, Malang
}

\author{
Zahrotul Musyayadah, Ika Ratna Hidayati, Rizka Novia Atmadani* \\ Departemen Farmasi, Fakultas Ilmu Kesehatan, Universitas Muhammadiyah Malang, Indonesia \\ *Corresponding author: rizkanovia@umm.ac.id
}

\begin{abstract}
Background: Family Planning is an attempt to regulate the birth of a child, distance and the ideal age of the childbirth, control pregnancy through the promotion protection, and assistance based on reproduction rights in creating a qualified and adequate family. There was a decline in the use of various contraceptives throughout Indonesia in 2020, which decreased by up to $10 \%$ due to public concerns about visiting health facilities during the Covid-19 pandemic. The decrease in contraceptive use causes an increase in the number of unplanned pregnancies by $15 \%$ in 2021, so it is necessary to increase the use of contraception to achieve the goals of the family planning program. In Indonesia, the most common contraception method used is the injection method. Purposes: The study aims to determine the relationship between knowledge and attitudes of women of childbearing age using contraceptive injection. Methods: uses observational analytics with a cross-sectional approach. The sampling technique used is accidental sampling, and there are 48 respondents obtained. The data analysis used is Chisquare testing. Result: Respondents with good knowledge of 52\%, 44\% Average knowledge, and $4 \%$ poor knowledge. Respondents with a positive attitude are $58 \%$, and a negative attitude is $42 \%$. The use of injected contraception stands at $70.8 \%$. The result of significant value using chi-square, value for the knowledge 0.602 and the attitude that 0.915. Conclusion: The respondents' knowledge with a good category is 52\%, while respondents with a positive attitude are 28\%, and the use of injected contraception stands with $70.8 \%$. The significant value using Chi-square is the value for the knowledge 0.602 and the attitude that 0.915. It can be concluded that there is no relationship between the knowledge and the attitudes of women of childbearing age toward the use of contraceptive injection in the public health center Lowokwaru District.
\end{abstract}

Keywords: the use of contraceptive injection, knowledge, attitude

\begin{abstract}
ABSTRAK
Latar belakang: Keluarga Berencana $(\mathrm{KB})$ adalah upaya untuk mengatur kelahiran anak, jarak dan usia ideal melahirkan, mengatur kehamilan melalui promosi, perlindungan, dan bantuan sesuai dengan hak reproduksi untuk mewujudkan keluarga yang berkualitas. Terjadi penurunan penggunaan berbagai alat kontrasepsi di seluruh Indonesia pada tahun 2020, yaitu mengalami penurunan hingga $10 \%$ yang dikarenakan kekhawatiran masyarakat untuk mendatangi fasilitas kesehatan pada masa pandemi Covid-19. Penurunan penggunaan kontrasepsi menyebabkan meningkatnya jumlah kehamilan tidak direncanakan sebanyak 15\% pada tahun 2021 sehingga perlu ditingkatkan dalam penggunaan kontrasepsi untuk mencapai tujuan program KB. Di
\end{abstract}


Indonesia metode yang paling banyak dipakai adalah metode kontrasepsi jenis suntik. Tujuan: mengetahui hubungan antara pengetahuan dan sikap Wanita Usia Subur (WUS) terhadap pemakaian alat kontrasepsi hormonal suntik. Metode: Metode Penelitian yang digunakan yaitu observasional analitik dengan pendekatan cross-sectional. Teknik sampling yang digunakan yaitu accidental sampling, sehingga didapatkan hasil sejumlah 48 responden. Analisis data yang digunakan yaitu dengan uji Chi-square. Hasil: responden yang memiliki pengetahuan yang baik $52 \%$, pengetahuan cukup $44 \%$ dan pengetahuan kurang $4 \%$. Responden memiliki sikap positif 58\% dan sikap negatif $42 \%$. Pemakaian KB suntik sebanyak 70,8\%. Hasil nilai signifikansi uji Chi-square diperoleh nilai p-value untuk pengetahuan 0,602 dan sikap yaitu 0,915. Simpulan: pengetahuan responden kategori baik sebanyak 52\%, sikap positif responden sebanyak $28 \%$ dan pemakaian KB suntik sebanyak 70,8\%. Hasil nilai signifikansi uji Chisquare diperoleh nilai $p$-value untuk pengetahuan 0,602 dan sikap yaitu 0,915, sehingga dapat disimpulkan tidak terdapat hubungan pengetahuan dan sikap terhadap pemakaian alat kontrasepsi hormonal suntik di Puskesmas Kecamatan Lowokwaru.

Kata kunci: pemakaian alat kontrasepsi hormonal suntik, pengetahuan, sikap

\section{PENDAHULUAN}

Indonesia memiliki jumlah penduduk terpadat keempat di dunia dengan jumlah populasi sekitar 250 juta penduduk. Sekitar setengah dari populasi penduduk Indonesia berada pada usia dibawah 30 tahun, hal ini terjadi karena angka kelahiran maupun tingkat kesuburan sama-sama mengalami penurunan dengan cepat sedangkan penduduk usia kerja meningkat dengan cepat. Kondisi tersebut menunjukkan bahwa di Indonesia memiliki jumlah penduduk usia produktif yang sangat tinggi. Kondisi ini jika dilihat dari potensi kesehatan, dapat mempengaruhi status atau derajat kesehatan apabila usia produktif tersebut tidak dikendalikan dengan baik karena semakin meningkatkan laju pertumbuhan penduduk di Indonesia (1). Rata-rata laju pertumbuhan penduduk di Indonesia pada tahun 2010-2020 sebesar $1,25 \%$ per tahun (2).

Usaha untuk mengatasi permasalahan penduduk di Indonesia, maka pemerintah membuat Undang-Undang Nomor 52 Tahun 2009 Tentang Perkembangan Kependudukan dan Pembangunan Keluarga, pada pasal 1 ayat 8 disebutkan bahwa Keluarga Berencana (KB) adalah upaya untuk mengatur kelahiran anak, jarak dan usia ideal melahirkan, mengatur kehamilan, melalui promosi, perlindungan, dan bantuan sesuai dengan hak reproduksi untuk mewujudkan keluarga yang berkualitas (3). Usaha untuk mencapai hal tersebut, maka dibuatlah beberapa cara atau alternatif yakni kontrasepsi atau mencegah bertemunya sperma dengan ovum, sehingga tidak terjadi pembuahan yang mengakibatkan kehamilan (4). Prevalensi Penggunaan Kontrasepsi atau Contraceptive Prevalence Rate (CPR) di Indonesia pada tahun 2015-2019 cenderung meningkat, sementara Angka Fertilitas atau Total Fertility Rate (TFR) cenderung menurun. Hal ini menunjukkan bahwa meningkatnya cakupan Wanita Usia Subur (WUS) yang melakukan KB sejalan dengan menurunnya angka fertilitas nasional (5).

Sasaran program KB adalah Pasangan Usia Subur (PUS) yang lebih dititikberatkan pada kelompok Wanita Usia Subur (WUS) yang berada pada kisaran usia 15-49 tahun (6). Alat kontrasepsi yang banyak menjadi pilihan dari Pasangan Usia Subur (PUS) yakni jenis alat kontrasepsi 
suntik. Karena alasan pemakaiannya yang aman, kerjanya sangat efektif, pemakaiannya sangat praktis, harganya murah, dan tidak membutuhkan pemakaian setiap hari (7).

KB suntik adalah suatu alat kontrasepsi hormonal dengan cara penggunaannya disuntikkan secara intramuskular (IM). Ada 2 macam jenis KB suntik, yakni golongan progestin, misalnya Depo Provera $150 \mathrm{mg}$ (disuntikkan setiap 3 bulan), Depo Noristerat $200 \quad \mathrm{mg}$ (disuntikkan setiap 2 bulan), dan golongan progestin dengan campuran estrogen propionat. Misalnya, cyclofem (disuntikkan setiap 1 bulan). Jenis $\mathrm{KB}$ suntik tersebut memiliki berbagai efek samping antara lain di bulan pertama pemakaian terjadi mual, sakit kepala, pendarahan berupa bercak diantara masa haid dan nyeri payudara (8).

$$
\text { Berdasarkan Data Badan }
$$

Kependudukan dan Keluarga Berencana Nasional (BKKBN) tahun 2019, bahwa Pasangan Usia Subur (PUS) di Indonesia sebanyak 38.690.214. Peserta KB aktif yang menggunakan metode kontrasepsi suntik mencapai $63,7 \%$, kontrasepsi pil $17,0 \%$, implant $7,4 \%$, MOW $2.7 \%$, MOP $0,5 \%$, IUD $7,4 \%$ dan kondom $1,2 \%$. Cakupan peserta KB aktif di provinsi Jawa Timur menggunakan metode suntikan adalah yang terbanyak yaitu $62,5 \%$ dan pil $18,3 \%$ diikuti IUD 7,2\%, implant $6,0 \%$, MOW 3,6\%, kondom 1,0\%, MOP 0,7\% (9).

Cakupan peserta KB aktif di Kota Malang menggunakan kontrasepsi jenis suntik sebesar $62,2 \%$ diikuti kontrasepsi jenis pil sebanyak 15,5\% dan IUD sebanyak $13,3 \%$. Hal yang sama juga terjadi pada peserta KB baru yang banyak menggunakan alat kontrasepsi jenis suntik mencapai $63,4 \%$ atau sebanyak 3.501 peserta. Berdasarkan data diatas dapat dilihat bahwa, mayoritas peserta $\mathrm{KB}$ di Kota Malang menggunakan kontrasepsi jenis suntik (10).

Perwakilan Badan Kependudukan dan Keluarga Berencana Nasional (BKKBN), menyatakan bahwa terjadi penurunan penggunaan berbagai alat kontrasepsi di seluruh Indonesia pada April 2020, yaitu mengalami penurunan hingga $10 \%$ yang dikarenakan kekhawatiran masyarakat untuk mendatangi fasilitas kesehatan pada masa pandemi Covid-19. Penurunan penggunaan kontrasepsi dapat menyebabkan peningkatan jumlah kehamilan tidak direncanakan sebanyak $15 \%$ pada tahun 2021 (11).

Teori Lawrence Green menjelaskan bahwa perilaku kesehatan termasuk didalamnya pemilihan alat kontrasepsi yang dipengaruhi oleh tiga faktor yaitu faktor predisposisi meliputi (umur, pekerjaan, pendidikan, pengetahuan dan sikap), faktor pemungkin (ketersediaan pelayanan kesehatan), dan faktor penguat (dukungan keluarga) (12). Faktor yang disebutkan diatas merupakan hal yang penting untuk diketahui karena dapat mempengaruhi pengambilan keputusan seseorang dalam pemakaian alat kontrasepsi.

Suntik memiliki resiko kegagalan yang cukup tinggi jika dibandingkan dengan metode KB lainnya. Kegagalan penggunaan metode kontrasepsi terjadi disebabkan karena kurangnya pengetahuan wanita terhadap alat kontrasepsi tersebut sehingga memberikan pengaruh terhadap perilaku, persepsi, motivasi dan tindakan terhadap kehamilan (13). Pengetahuan akseptor KB berhubungan dengan penggunaan alat kontrasepsi bahwa semakin tinggi tingkat pendidikan seseorang maka semakin baik pengetahuan seseorang terhadap penggunaan alat 
kontrasepsi dan semakin rasional dalam menggunakan alat kontrasepsi (14).

Penelitian yang dilakukan sebelumnya di Klinik Pratama Sartika Bandar Lampung menyatakan bahwa ada hubungan antara pengetahuan dengan penggunaan kontrasepsi suntik. Hal ini disebabkan karena seseorang dengan pengetahuan yang cukup baik akan lebih mempertimbangkan pemilihan alat kontrasepsi dilihat dari segi keekonomisan daripada efek samping yang diakibatkan dari pemakaian alat kontrasepsi itu sendiri. Sikap akseptor KB memiliki hubungan yang bermakna dalam pemakaian $\mathrm{KB}$ suntik dapat dilihat jenis KB ini praktis dan murah apabila dibandingkan dengan KB yang lainnya dan sikap yang cenderung tidak peduli terhadap efek samping $\mathrm{KB}$ sehingga mereka akan tetap memilih $\mathrm{KB}$ yang menurut mereka cocok (15).

Kota Malang diketahui memiliki empat kecamatan yang masing-masing kecamatan memiliki tiga puskesmas. Menurut Dinas Kesehatan Kota Malang, data akseptor KB Suntik tertinggi adalah di Kecamatan Lowokwaru yaitu pada Puskesmas Dinoyo berjumlah 7.959 orang, Puskesmas Mojolangu berjumlah 4.362 orang dan Puskesmas Kendalsari 4.804 orang. Tingginya partisipasi akseptor KB terhadap penggunaan alat kontrasepsi suntik serta terjadinya penurunan penggunaan berbagai alat kontrasepsi membuat peneliti tertarik untuk melakukan penelitian tentang hubungan pengetahuan dan sikap wanita usia subur terhadap pemakaian alat kontrasepsi hormonal suntik di Puskesmas Kecamatan Lowokwaru Kota Malang yaitu Puskesmas Dinoyo, Kendalsari dan Mojolangu.

\section{METODE}

Penelitian ini bersifat observasional analitik dengan pendekatan studi cross-sectional (16). Populasi yang digunakan dalam penelitian ini adalah seluruh akseptor KB yang berkunjung di Puskesmas Kecamatan Lowokwaru Kota Malang. Teknik pengambilan sampel yang dilakukan dalam penelitian ini adalah dengan metode nonprobability sampling dengan pendekatan accidental sampling. Jumlah populasi akseptor KB yang berkunjung di Puskesmas Kecamatan Lowokwaru Kota Malang adalah sebanyak 93 Akseptor. Penelitian ini menggunakan rumus Slovin untuk menentukan jumlah sampel sehingga jumlah responden yang didapatkan sebanyak 48 responden.

Kriteria inklusi adalah kriteria atau ciri-ciri yang perlu dipenuhi oleh setiap anggota populasi yang dapat diambil sebagai sampel. Kriteria inklusi yang dapat diterapkan pada populasi sumber sampel adalah wanita usia subur yang merupakan akseptor KB di Puskesmas Kecamatan Lowokwaru Kota Malang, bersedia menjadi responden dari penelitian serta mengisi kuesioner dan responden mampu membaca, menulis, berkomunikasi menggunakan bahasa Indonesia dengan baik. Kriteria eksklusi adalah responden yang datanya tidak lengkap (17).

Instrumen yang digunakan dalam penelitian ini adalah kuesioner data demografi, kuesioner pemakaian alat kontrasepsi, kuesioner pengetahuan, serta kuesioner sikap terhadap pemakaian alat kontrasepsi hormonal suntik. Penggunaan kuesioner dalam penelitian ini, dibuat sendiri oleh peneliti yang diambil dari teori/ referensi terkait, yang terdiri atas 7 item pernyataan pengetahuan dan 8 item pertanyaan sikap yang telah diuji validitas dan reliabilitasnya. Uji validitas dan 
reliabilitas dilakukan di Puskesmas Kecamatan Lowokwaru Kota Malang dengan mengambil data responden yang bukan merupakan responden penelitian dilakukan dengan cara memberikan kuesioner kepada 30 responden. Uji validitas dan reliabilitas dilakukan menggunakan bantuan Software SPSS 23.0. Validitas kuesioner diketahui jika nilai $\mathrm{r}$ hitung lebih besar dari $r$ tabel $(0,374)$. Hasil item kuesioner yang terdiri dari 7 item terkait pengetahuan dan 8 item terkait sikap dinyatakan valid selanjutnya dilakukan uji reliabilitas didapatkan hasil reliabilitas pengetahuan sebesar 0,818 dan sikap sebesar 0,827 . Pengisian kuesioner tersebut dilakukan dengan memberi tanda centang $(\sqrt{ })$ pada jawaban yang dianggap benar oleh responden.

Variabel bebas dalam penelitian ini yaitu pengetahuan dan sikap wanita usia subur tentang alat kontrasepsi hormonal suntik. Variabel terikat dalam penelitian ini yaitu pemakaian alat kontrasepsi hormonal suntik.

Pengetahuan masyarakat terhadap pemakaian alat kontrasepsi hormonal suntik diolah dengan skala Guttman. Pengetahuan berupa 7 pertanyaan dengan kriteria pertanyaan dengan jawaban "benar" diberi skor 1 dan jawaban "salah" diberi skor 0 . Pengetahuan dapat dikategorikan menjadi tiga kategori yaitu baik dengan presentase 76-100\%, cukup dengan presentase $56-75 \%$, kurang dengan presentase $\leq 55 \%$ (17).

Sikap masyarakat terhadap pemakaian alat kontrasepsi hormonal suntik diolah dengan skala Likert. Sikap berupa 8 pertanyaan, sehingga responden diminta untuk menyatakan pendapatnya yaitu sangat setuju (SS), Setuju (S), Tidak Setuju (TS), Sangat Tidak Setuju (STS). Masing- masing skala diberi skor dengan ketentuan untuk pertanyaan jawaban sangat setuju (SS) di beri skor 4, Setuju (S) diberi skor 3, Tidak Setuju (TS) diberi skor 2, Sangat Tidak Setuju (STS) diberi skor 1. Hasil skoring yang telah didapatkan tersebut dapat dikategorikan menjadi "ingin menggunakan" (sikap positif), jika nilai skor $\mathrm{T} \geq$ rata-rata (50) dan dinyatakan "tidak ingin menggunakan" (sikap negatif), jika nilai skor $\mathrm{T}<$ rata-rata (50) (18).

Data dalam penelitian ini dilakukan analisis univariat dan bivariate menggunakan SPSS. Analisis univariat pada penelitian ini yaitu distribusi frekuensi pengetahuan, sikap dan pemakaian alat kontrasepsi hormonal suntik. Hasil analisa data univariat akan ditampilkan dalam bentuk persentase. Analisis bivariat ditujukan untuk melihat hubungan antara variabel terikat dengan variabel bebas (19). Analisis bivariat menggunakan uji chisquare, tingkat kepercayaan yang digunakan atau tingkat signifikansi sebesar $p(\alpha)=0,05$ yang artinya digunakan untuk mengetahui ada atau tidaknya hubungan antara pengetahuan dan sikap wanita usia subur terhadap pemakaian alat kontrasepsi hormonal suntik $(20,21)$.

Penelitian ini sudah mendapatkan izin penelitian dari Komisi Etik Penelitian Kesehatan (KEPK) Fakultas Kedokteran UMM dengan No.E.5.a/115/KEPKUMM/V/2021.

\section{HASIL}

Penelitian ini dilakukan pada tanggal 03 Juni sampai 08 Juli 2021 di seluruh Puskesmas Kecamatan Lowokwaru Kota Malang yaitu Puskesmas Dinoyo, Kendalsari dan Mojolangu. Partisipan pada penelitian ini adalah 48 orang yaitu wanita usia subur yang merupakan akseptor KB di Puskesmas Kecamatan Lowokwaru. Hasil penelitian disajikan dalam bentuk tabel dan 
yang didasarkan pada analisis univariat dan bivariat.

Tabel 1. Karakteristik Data Pendukung Responden

\begin{tabular}{|c|c|c|c|}
\hline \multirow{2}{*}{\multicolumn{2}{|c|}{$\begin{array}{c}\text { Data } \\
\text { Pendukung } \\
\text { Usia Responden }\end{array}$}} & $\begin{array}{c}\text { Jumlah } \\
\text { Responden }\end{array}$ & $\begin{array}{c}\text { Presentase } \\
(\%)\end{array}$ \\
\hline & & & \\
\hline \multicolumn{2}{|c|}{ 20-35 tahun } & 17 & 35,4 \\
\hline \multicolumn{2}{|c|}{ 36-49 tahun } & 31 & 64,6 \\
\hline \multicolumn{4}{|c|}{ Pendidikan Responden } \\
\hline \multicolumn{2}{|l|}{ SD } & 6 & 12,5 \\
\hline \multicolumn{2}{|l|}{ SMP } & 12 & 25 \\
\hline \multicolumn{2}{|l|}{ SMA } & 19 & 39,6 \\
\hline \multicolumn{2}{|c|}{ Perguruan Tinggi } & 11 & 22,9 \\
\hline \multicolumn{4}{|c|}{ Pekerjaan Responden } \\
\hline \multicolumn{2}{|c|}{$\begin{array}{ll}\text { Ibu } & \text { Rumah } \\
\text { Tangga } & \end{array}$} & 34 & 70,8 \\
\hline \multicolumn{2}{|l|}{ Petani } & 1 & 2,1 \\
\hline \multicolumn{2}{|c|}{ Wiraswasta } & 4 & 8,3 \\
\hline \multicolumn{2}{|c|}{ Lain-lain } & 9 & 18,8 \\
\hline \multicolumn{4}{|c|}{ Pendapatan Responden } \\
\hline \multicolumn{2}{|c|}{$<$ Rp.500.000 } & 9 & 18,8 \\
\hline \multicolumn{2}{|c|}{$\begin{array}{l}\text { Rp.500.000- } \\
\text { Rp.1.000.000 }\end{array}$} & 12 & 25 \\
\hline \multicolumn{2}{|c|}{ Rp.1.000.000- } & 17 & 35,4 \\
\hline \multicolumn{2}{|c|}{$>$ Rp.2.000.000 } & 10 & 20,8 \\
\hline \multicolumn{4}{|c|}{ Pemakaian Kontrasepsi } \\
\hline \multicolumn{2}{|c|}{ KB Suntik } & 34 & 70,8 \\
\hline \multicolumn{2}{|l|}{ Pil } & 6 & 12,5 \\
\hline \multicolumn{2}{|l|}{ Implan } & 3 & 6,3 \\
\hline \multicolumn{2}{|l|}{ IUD } & 5 & 10,4 \\
\hline \multicolumn{4}{|c|}{ Jenis KB Suntik } \\
\hline \multicolumn{3}{|l|}{ Bulan } & 32,4 \\
\hline \multicolumn{2}{|l|}{$\begin{array}{l}\text { Suntik } \\
\text { Bulan }\end{array}$} & 23 & 67,6 \\
\hline \multicolumn{4}{|c|}{ Pengetahuan Responden } \\
\hline \multicolumn{2}{|l|}{ Baik } & 25 & 52 \\
\hline Cukup & & 21 & 44 \\
\hline Kurang & & 2 & 4 \\
\hline Sikap $R e$ & sponden & & \\
\hline Positif & & 28 & 58 \\
\hline Negatif & & 20 & 42 \\
\hline
\end{tabular}

Pada Tabel 1 dapat dilihat bahwa responden pada penelitian ini mayoritas berusia 36-49 tahun dengan hasil 64,6 \%, pendidikan responden paling banyak pada tingkat SMA dengan hasil 39,6 \%, pekerjaan responden terbanyak adalah sebagai Ibu Rumah Tangga/Tidak bekerja dengan hasil 70,8 \%, pendapatan responden paling banyak yaitu Rp. 1.000.000-Rp. 2.000 .000 dengan hasil $35,4 \%$, alat kontrasepsi yang paling banyak dipakai responden adalah $\mathrm{KB}$ suntik sebanyak 70,8 $\%$, jenis $\mathrm{KB}$ suntik yang paling banyak dipilih responden adalah $\mathrm{KB}$ suntik 3 bulan sebanyak 67,6 \%, mayoritas pasien memiliki pengetahuan yang baik terhadap pemakaian $\mathrm{KB}$ suntik yaitu sebesar 52\% dan mayoritas pasien memiliki sikap yang positif dalam pemakaian KB suntik yaitu sebesar $58 \%$.

Tabel 2. Uji Chi-square Pengetahuan dan Sikap Terhadap Pemakaian Alat Kontrasepsi Suntik

\begin{tabular}{|c|c|c|c|c|c|c|c|c|}
\hline & & \multicolumn{4}{|c|}{$\begin{array}{c}\text { Pemakaian Alat } \\
\text { Kontrasepsi } \\
\text { Suntik }\end{array}$} & \multirow{2}{*}{\multicolumn{2}{|c|}{ Total }} & \multirow[t]{2}{*}{$\begin{array}{c}\text { P- } \\
\text { value }\end{array}$} \\
\hline & & \multicolumn{2}{|c|}{$\mathrm{Ya}$} & \multicolumn{2}{|c|}{ Tidak } & & & \\
\hline \multirow{3}{*}{$\begin{array}{c}\text { Pengeta- } \\
\text { huan }\end{array}$} & & $\mathrm{n}$ & $\%$ & $\mathrm{n}$ & $\%$ & $\mathrm{n}$ & $\%$ & \multirow{4}{*}{0,602} \\
\hline & Kurang & 2 & 6 & 0 & 0 & 2 & 4 & \\
\hline & Cukup & 14 & 41 & 7 & 50 & 21 & 44 & \\
\hline \multirow{3}{*}{ Sikap } & Baik & 18 & 53 & 7 & 50 & 25 & 52 & \\
\hline & Negatif & 14 & 41 & 6 & 43 & 20 & 42 & \multirow{2}{*}{0,915} \\
\hline & Positif & 20 & 59 & 8 & 57 & 28 & 58 & \\
\hline
\end{tabular}

Pada uji Chi-square antara variabel pengetahuan dengan pemakaian dilihat pada Tabel 2 diperoleh bahwa wanita usia subur yang memiliki tingkat pengetahuan baik dan memakai alat kontrasepsi suntik yaitu sebesar 53\% dibandingkan dengan responden yang tidak memakai alat kontrasepsi suntik yaitu sebesar 50\%, responden dengan pengetahuan cukup dan memakai alat kontrasepsi suntik $41 \%$, dan yang tidak memakai 50\%. Responden dengan pengetahuan yang kurang dan memakai alat kontrasepsi suntik yaitu 
sebesar $6 \%$ dan yang tidak memakai $0 \%$. Dari hasil uji Chi-square diperoleh p-value 0,602 sehingga dapat dikatakan bahwa tidak terdapat hubungan antara pengetahuan wanita usia subur terhadap pemakaian kontrasepsi suntik.

Pada uji Chi-square antara variabel sikap dengan pemakaian dilihat pada Tabel 2 diperoleh bahwa wanita usia subur yang memiliki sikap positif dan memakai alat kontrasepsi suntik yaitu sebesar 59\% dibandingkan dengan responden yang tidak memakai alat kontrasepsi suntik yaitu sebesar 57\%. Responden dengan sikap negatif dan memakai alat kontrasepsi suntik $41 \%$ dan yang tidak memakai $43 \%$. Dari hasil uji Chi-square diperoleh p-value 0,915, sehingga dapat dihasilkan bahwa tidak terdapat hubungan antara sikap wanita usia subur terhadap pemakaian kontrasepsi suntik.

\section{PEMBAHASAN}

\section{Analisis Hubungan Pengetahuan Wanita Usia Subur terhadap Pemakaian KB Suntik}

Berdasarkan hasil penelitian, bahwa responden yang memiliki pengetahuan baik dan memakai alat kontrasepsi suntik yaitu sebanyak 18 orang (53\%) dibandingkan dengan responden yang tidak memakai alat kontrasepsi suntik yaitu sebanyak 7 orang (50\%). Responden dengan pengetahuan cukup dan memakai alat kontrasepsi suntik sebanyak 14 orang (41\%) dan yang tidak memakai 7 orang (50\%). Responden dengan pengetahuan yang kurang dan memakai alat kontrasepsi suntik yaitu sebanyak 2 orang $(6 \%)$ dan yang tidak memakai 0 orang $(0 \%)$. Hasil tersebut maka dapat dikatakan bahwa semakin baik tingkat pengetahuan seseorang, maka semakin tinggi akseptor $\mathrm{KB}$ yang memakai KB suntik. Pernyataan ini diperkuat dengan adanya penelitian sebelumnya yang menyatakan bahwa semakin baik pengetahuan seseorang tentang $\mathrm{KB}$ suntik semakin banyak pula akseptor yang memakai KB suntik (22).

Hasil penelitian menunjukkan bahwa p-value $0,602>0,05$ sehingga dapat disimpulkan bahwa tidak terdapat hubungan antara pengetahuan wanita usia subur terhadap pemakaian kontrasepsi suntik. Hasil penelitian ini tidak sejalan dengan penelitian sebelumnya di Desa Humbia Kecamatan Tagulandang Selatan Kabupaten Sitaro, yang menyatakan bahwa terdapat hubungan antara pengetahuan dengan pemakaian alat kontrasepsi suntik. Hal ini dikarenakan responden dengan tingkat pengetahuan yang baik tentang kontrasepsi suntik lebih banyak memilih untuk memakai kontrasepsi suntik (23). Adapun hasil penelitian ini sejalan dengan penelitian yang dilakukan sebelumnya di Puskesmas Swasti Kota Lubuklinggau, yang menunjukkan bahwa nilai signifikan $\mathrm{p}>\alpha(0,05)$ yaitu $\mathrm{p}=0,129$. Disimpulkan bahwa tidak ada hubungan yang bermakna antara pengetahuan dengan pemakaian alat kontrasepsi suntik (24). Hasil penelitian ini juga sejalan dengan penelitian yang dilakukan sebelumnya di Desa Binangon Kecamatan Muara Komam, yang menunjukkan bahwa nilai signifikan $p>\alpha(0,05)$ yaitu $p=0,857$, dengan demikian disimpulkan bahwa tidak ada hubungan yang bermakna antara pengetahuan ibu usia subur dengan pemakaian alat kontrasepsi suntik (25).

Sebuah teori WHO menjelaskan bahwa pengetahuan bisa dipengaruhi oleh pengalaman seseorang dan faktor lingkungan. Pengalaman tersebut diketahui, diapresiasikan, diyakini sebagai akibatnya bisa muncul motivasi serta niat untuk bertindak sehingga terjadi 
perwujudan niat berbentuk sikap. Sesuai teori tersebut dapat ditarik kesimpulan bahwa pemakaian kontrasepsi suntik tidak hanya dipengaruhi oleh pengetahuan namun pula bisa dipengaruhi ketidak cocokan individu pada pemakaian alat kontrasepsi suntik, seperti haid tidak teratur, penambahan berat badan serta banyak faktor lain yang mempengaruhi pengetahuan seseorang (24).

Ibu usia subur yang memiliki pengetahuan yang baik terhadap alat kontrasepsi suntik belum tentu akan memakai kontrasepsi suntik (26), khususnya ibu-ibu di Puskesmas Kecamatan Lowokwaru karena banyak hal yang harus dipertimbangkan yaitu kenyamanan dan resiko sehingga hasil penelitian ini menghasilkan hubungan yang tidak signifikan.

\section{Analisis Hubungan Sikap Wanita Usia Subur terhadap Pemakaian KB Suntik}

Berdasarkan hasil penelitian, bahwa responden yang memiliki sikap positif dan memakai alat kontrasepsi suntik yaitu sebanyak 20 orang (59\%) dibandingkan dengan responden yang tidak memakai alat kontrasepsi suntik yaitu sebanyak 8 orang (57\%). Responden dengan sikap negatif dan memakai alat kontrasepsi suntik yaitu sebanyak 14 orang (41\%) dan yang tidak memakai 6 orang (43\%). Sikap merupakan salah satu faktor predisposisi yang dapat menentukan suatu individu untuk bertindak, semakin baik sikap terhadap program KB maka semakin banyak kemungkinan untuk ikut aktif dalam pelaksanaan program KB (27).

Hasil penelitian menunjukkan bahwa nilai p-value 0,915>0,05 sehingga dapat disimpulkan bahwa tidak terdapat hubungan antara sikap wanita usia subur terhadap pemakaian kontrasepsi suntik.
Hasil penelitian ini tidak sejalan dengan penelitian sebelumnya yang dilakukan di Desa Jejangkit Pasar Kecamatan Jejangkit Kabupaten Barito Kuala, yang menyatakan bahwa ada hubungan antara sikap ibu usia subur dengan pemakaian alat kontrasepsi suntik. Hal ini dikarenakan sikap akseptor KB yang cenderung tidak peduli terhadap kekhawatiran yang dialami, merasa cocok, praktis, dan murah (28). Adapun hasil penelitian ini sejalan dengan penelitian yang dilakukan sebelumnya di Desa Humbia Kecamatan Tagulandang Selatan Kabupaten Sitaro, yang menunjukkan bahwa nilai signifikan $\mathrm{p}>\alpha(0,05)$ yaitu $\mathrm{p}=0,517$. Berdasarkan hal tersebut dikatakan bahwa tidak terdapat hubungan yang bermakna antara sikap dengan pemakaian alat kontrasepsi suntik (23).

Hasil penelitian ini juga sejalan dengan penelitian yang dilakukan sebelumnya di Puskesmas Minasaupa Makassar, yang menunjukkan bahwa nilai signifikan $p>\alpha \quad(0,05)$ yaitu $p=0,101$. Berdasarkan hal tersebut dikatakan bahwa tidak terdapat hubungan yang bermakna antara sikap ibu dengan pemakaian alat kontrasepsi suntik (29). Hal ini dikarenakan responden dengan sikap positif maupun negatif lebih banyak memakai kontrasepsi suntik sehingga hasil penelitian ini menghasilkan hubungan yang tidak signifikan dimana tidak terdapat hubungan antara variabel bebas dengan terikatnya (30-33). Menurut peneliti hasil tidak signifikan kerana sampel yang digunakan terlalu sedikit, sehingga penelitian ini menghasilkan hubungan yang tidak signifikan. Peneliti tetap mengangkat variabel ini karena perilaku seseorang didasari oleh pengetahuan dan sikap yang positif sehingga variabel ini dapat mempengaruhi perilaku wanita usia subur dalam pemakaian alat kontrasepsi suntik 
dan dari hasil penelitian sebelumnya yang dilakukan menunjukkan hasil yang signifikan sehingga peneliti ingin menguji apakah hasil akan tetap sama apabila dilakukan di tempat yang berbeda.

\section{SIMPULAN}

Berdasarkan data yang diperoleh, beserta analisa dan interpretasi dari hasil penelitian tentang hubungan pengetahuan dan sikap wanita usia subur terhadap pemakaian alat kontrasepsi hormonal suntik di Puskesmas Kecamatan Lowokwaru, Kota Malang, dapat disimpulkan bahwa pasien memiliki pengetahuan yang baik sebanyak (52\%), pengetahuan cukup sebanyak sebesar (44\%) dan pengetahuan kurang sebesar (4\%). Pasien memiliki sikap positif sebanyak sebanyak (58\%) dan memiliki sikap negatif sebanyak sebanyak (42\%). Berdasarkan beberapa hasil tersebut didapatkan bahwa tidak terdapat hubungan antara pengetahuan wanita usia subur terhadap pemakaian alat kontrasepsi hormonal suntik di Puskesmas Kec. Lowokwaru dengan nilai signifikansi 0.602 dan tidak terdapat hubungan antara sikap wanita usia subur terhadap pemakaian alat kontrasepsi hormonal suntik di Puskesmas Kec. Lowokwaru dengan nilai signifikansi 0.915 .

\section{UCAPAN TERIMA KASIH}

Segala puji dan syukur penulis panjatkan kehadirat Allah SWT karena limpahan rahmat, hidayah dan Inayah-Nya penulis dapat menyelesaikan penelitian yang berjudul "Hubungan Pengetahuan dan Sikap Wanita Usia Subur Terhadap Pemakaian Alat Kontrasepsi Hormonal Suntik di Puskesmas Kec. Lowokwaru". Ucapan terimakasih disampaikan kepada semua pihak yang telah membantu serta mendukung dalam proses penyusunan.
Penulis berharap penelitian ini dapat memberikan manfaat bagi perkembangan ilmu pengetahuan.

\section{KONFLIK KEPENTINGAN}

Penulis tidak memiliki konflik kepentingan dengan organisasi manapun yang dapat menimbulkan pertanyaan bias.

\section{REFERENSI}

1. Sulistyorini E. Hubungan Tingkat Pengetahuan Dengan Minat Terhadap Jenis Kontrasepsi Pasca Salin Pada Ibu Nifas di RB Sukoasih Sukoharjo Tahun 2016. J Kebidanan Indones. 2016;7(2):21-36.

2. Badan Pusat Statistik. Hasil Sensus Penduduk 2020. Jakarta Pusat: Badan Pusat Statistik. 2021.

3. Ramadhan MH, Idami Z. Pengendalian Laju Pertumbuhan Penduduk Melalui Program Keluarga Berencana di Kota Banda Aceh. J Gov Soc Policy. 2020;1(1):47-56.

4. Purbowati MR. Pengaruh Penggunaan IUD Terhadap Penyakit Keputihan di Puskesmas Kebasan Kabupaten Banyumas. J Ilm Ilmuilmu Kesehat. 2015;13(3):20-8.

5. BKKBN. Laporan Akuntabilitas Kerja Instansi Pemerintah. Jakarta: BKKBN. 2019.

6. Saragih HR. Hubungan Pengetahuan dan Sikap Ibu Pasangan Usia Subur dengan Penggunaan Alat Kontrasepsi Dalam Rahim (AKDR) di Wilayah Kerja Puskesmas Pancur Batu Kabupaten Deli Serdang Tahun 2017. J Ilm PANNMED. 2018;12(3):267-72.

7. Norlita W, Isnaniar, Shafitri E. Hubungan Antara Pemakaian Alat Kontrasepsi Suntik dengan 
Hipertensi pada Akseptor KB Suntik

di Puskesmas Harapan Raya Pekanbaru. Phot J Sain dan Kesehat. 2018;9(1):130-8.

8. Affandi B. Buku Panduan Praktis Pelayanan Kontrasepsi. Jakarta: Jakarta : PT Bina Pustaka Sarwono Prawirohardjo.; 2016. 36-43 p.

9. Kemenkes RI. Data dan Informasi Profil Kesehatan Indonesia 2019. Kemenkes RI. 2019;8(9):1-58.

10. Dinkes Kota Malang. Profil Kesehatan Kota Malang Tahun 2018. Dinas Kesehatan Kota Malang. Malang; 2018. p. 1-72.

11. Solahuddin G. Pandemi Covid-19 Usai Jumlah Bayi dan Ibu Melahirkan Naik, Kehamilan Meningkat Hingga 500 Ribu. HealthGrid. 2020;

12. Susilowati D. Promosi Kesehatan. Jakarta: Jakarta: Pusdik SDM Kesehatan, Kemenkes RI.; 2016.

13. Yuliari K, Mahayati NMD, Lindayani IK. Hubungan Pengetahuan Dengan Sikap Akseptor Dalam Menangani Efek Samping KB Suntik Tiga Bulan di Praktik Mandiri Bidan Hj. S., A. Md. Keb. J Ilm Kebidanan J Midwifery. 2019;7(2):110-5.

14. Rahayu I, Reza M, Usman E. Hubungan Pengetahuan Ibu Pasangan Usia Subur dengan Penggunaan Kontrasepsi IUD di Nagari Andalas Baruh Bukit Kecamatan Sungayang Kabupaten Tanah Datar. J Kesehat Andalas. 2018;7(Supplement 4):44.

15. Septalia R, Puspitasari N. Faktor yang Memengaruhi Pemilihan Metode Kontrasepsi. J Biometrika dan Kependud. 2016;5(2):91-8.

16. Sari NF, Hidayati IR, Atmadani RN.
Hubungan Pengetahuan tentang Penggunaan OAD pada Pasien Diabetes Mellitus Tipe 2 terhadap Kepatuhan Penggunaan Obat Antidiabetes Oral di Puskesmas Singosari Malang. J Kesehat Islam Islam Heal J. 2021;10(2):65-71.

17. Masturoh I, T. NA. Metodologi Penelitian Kesehatan. 1st ed. Jakarta: Kementrian Kesehatan RI; 2018. 5$6 \mathrm{p}$.

18. Ritonga F. Hubungan Pengetahuan dengan Sikap Ibu Pemilihan Metode Knntrasepsi Jangka Panjang Pada WUS Di Puskesmas Pembantu Kel. Sidorejo Hilir Medan. J Ilm Kebidanan Imelda. 2020;6(1):1-10.

19. Priyono. Metode Penelitian Kuantitatif. Chandra, editor. Sidoarjo: Zifatama PUBLISHING.; 2016.

20. Hidayati IR, Damayanti DA, Pristianty L. Journal of Global Pharma Technology Analysis of Behavioral Factors on Medications in Gout Patients with Health belief Model Theory. 2018;79-84.

21. Oktaviana E, Hidayati IR, Pristianty L. Pengaruh Pengetahuan terhadap Penggunaan Obat Parasetamol yang Rasional dalam Swamedikasi (Studi pada Ibu Rumah Tangga di Desa Sumberpoh Kecamatan Maron Kabupaten Probolinggo). J Farm Dan Ilmu Kefarmasian Indones. 2019;4(2):44.

22. Hasnani FH. Faktor yang Mempengaruhi Akseptor dalam Memilih Alat Kontrasepsi Suntik. Qual J Kesehat. 2019;13(1):22-7.

23. Jacobus RM, Maramis FRR, Mandagi CKF. Faktor-faktor yang Berhubungan dengan Penggunaan alat Kontrasepsi Suntik pada 
Akseptor KB di Desa Humbia

Kecamatan tagulandang Selatan

Kabupaten Sitaro. Vol. 7, Jurnal

Kesehatan Masyarakat. 2018. p. 1-8.

24. Hartini L, Prabusari OH. Hubungan

Tingkat Pengetahuan Ibu dan Usia Terhadap Penggunaan Alat Kontrasepsi Suntik. J Kesmas Asclepius. 2019;1(1):65-74.

25. Sawiti P. Hubungan Tingkat Pengetahuan Ibu tentang KB Suntik dengan Pemilihan Motode Kontrasepsi Suntik di Desa Binangon Kecamatan Muara Komam Tahun 2020. Skripsi. 2020;

26. Astuti D, Ilyas H. Faktor-Faktor Yang Berhubungan Dengan Pemilihan Alat Kontrasepsi Suntik. J Ilm Keperawatan Sai Betik. 2017;11(2):233-43.

27. Rosalina S. Gambaran Faktor Predisposing, Enabling Dan Reinforcing KB. J PROMKES. 2019;7(1):113.

28. Mardiah M. Hubungan Pengetahuan dan Sikap Akseptor KB Dengan Pemilihan Alat Kontrasepsi di Desa Jejangkit Pasar Kecamatan Jejangkit Kabupaten Barito Kuala. J Educ Nursing(Jen). 2019;2(1):85-94.

29. Amir F. Faktor-Faktor yang Berhubungan dengan Pemilihan Alat Kontrasepsi pada Pasangan
Usia Subur (PUS) di Puskesmas Minasaupa Makassar Tahun 2017. J Kesehat Delima Pelamonia. 2017;1(2):123-8.

30. Atmadani RN, Nkoka O, Yunita SL, Chen Y-H. Self-medication and knowledge among pregnant women attending primary healthcare services in Malang, Indonesia: a cross-sectional study. BMC Pregnancy Childbirth. 2020;20(1):1-11.

31. Putra DS, Atmadani RN, Hidayati IR. Relationship between knowledge level of hiv/aids patient with antiretroviral adherence in primary healthcare service in Malang City. J HIV AIDS Soc Serv. 2021 Aug;118.

32. Sari AM. The Relationship between The Level of Side Effects of ARV Drugs in ODHA Patients to The Level of The Compliance Use of ARV Drugs. Pharm J Indones. 2021;6(2):125-9.

33. Yunita SL, Atmadani RN, Titani M. Faktor-faktor Yang Mempengaruhi Pengetahuan Dan Perilaku Penggunaan Antibiotika Pada Mahasiswa Farmasi Universitas Muhammadiyah Malang. Pharm J Indones. 2021;6(2):119-23. 